\title{
Heart changes in a fetus of a diabetic mother
}

\author{
Julia S Pabis ${ }^{1}$, Letícia Schneider ${ }^{1}$, Luisa F Stoll ${ }^{1}$ and Mona A Simoes ${ }^{2 *}$ \\ ${ }^{1}$ University of the Region of Joinville, Brazil \\ ${ }^{2}$ Department of Perinatology, The Medicine University of Joinville University and LAPEN counselor, Brazil
}

\section{Clinical history}

Newborn female, term, suitable for gestational age, cesarean delivery, birth weight $3610 \mathrm{~g}$, APGAR 2/7, daughter of diabetic mother, depressed at birth, asymptomatic hypoglycemia, T 36.6o, FC: 108137, FR: 46-62, Sat O2: 92-96, colored, hydrated, active and reactive to handling.

\section{Maternal history}

Performed three prenatal consultations. She referred gestational diabetes in previous pregnancies, hypertension and denied a family history of heart disease. Serology for HIV, VDLR, HBsAg and Toxoplasmosis Negatives. She presented altered glycemia during pregnancy but did not undergo treatment.

\section{Physical exam}

Cardiologic: cardiac auscultation with hyperphonectic, rude sounds, with systolic murmur $1 \pm 6+$ in left sternal border.

\section{Complementary exams}

Cardiologic evaluation was requested for the newborn in the first hours of life due to cardiac auscultation.

At the echocardiographic examination, an important septal hypertrophy was observed obstructing the left ventricular outflow tract (Figures 1 and 2).

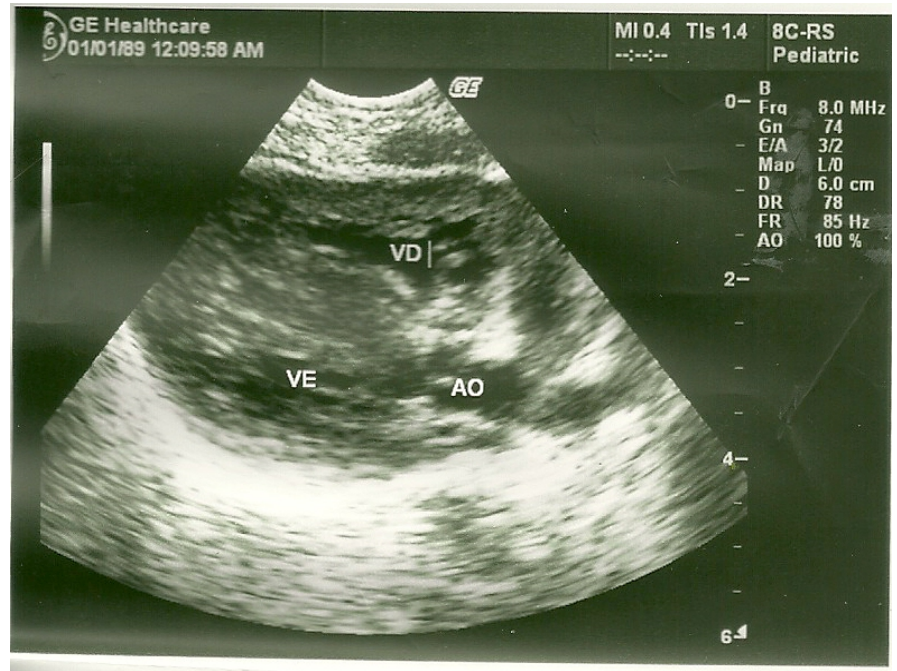

Figure 1. Long parasternal cut showing important septal hypertrophy

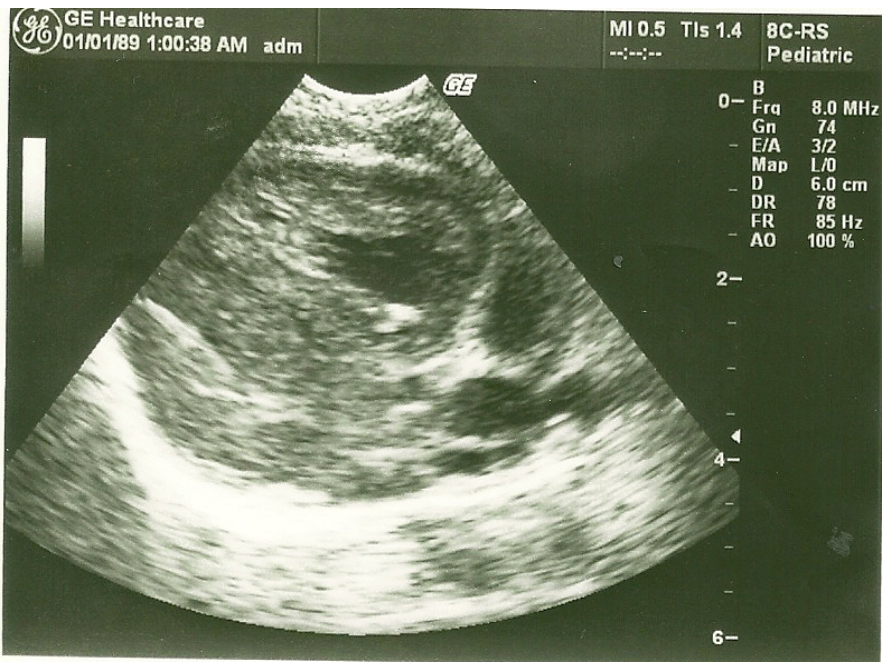

Figure 2. Long parasternal cut with the heart in systole demonstrating obstruction of the left ventricular outflow tract by hypertrophy

\section{Evolution}

After evaluation of the cardiologist and echocardiographic examination, cardiac monitoring in the intensive care unit, cardiovascular support medication and neurological, genetic and ophthalmologic assessment were used to rule out diseases associated with cardiomyopathy.

During the evolution, she presented episodes of tachypnoea and heart failure, and was discharged seven days old with orientation to the mother regarding signs of cardiovascular decompensation and cardiac outpatient management.

\section{Discussion points}

1. Does Gestational Diabetes influence the development of the fetus and the newborn?

2. What are the major fetal heart and newborn changes in gestational diabetes?

${ }^{\star}$ Correspondence to: Mona Adalgisa Simoes, Department of Perinatology, The Medicine University of Joinville University and LAPEN counselor, Brazil, E-mail: monasimoes@uol.com.br

Received: April 01, 2019; Accepted: April 17, 2019; Published: April 20, 2019 
3. What are the hypotheses for the causes of these cardiac changes due to gestational diabetes?

\section{Discussion}

We report a clinical case of a newborn of pregnant women with gestational diabetes, with inadequate prenatal control for diabetes. The child was born with an important hypertrophic cardiomyopathy probably due to inadequate prenatal management.

In research on the adaptation of fetal circulation after birth among fetuses of normal pregnant women and diabetic pregnant women, it was observed that the control of diabetes mellitus during pregnancy is fundamental in the development and maturation of the cardiovascular system of fetuses and newborns [1].

However, it is not possible to state that in the children of untreated and / or poorly controlled diabetic pregnant women, the cardiovascular system has the same evolution, given the known anatomical changes, such as myocardial hypertrophy.

It has been reported that left ventricular diastolic dysfunction may be involved in the genesis of frequent respiratory complications in children of diabetic pregnant women, such as respiratory distress and transient tachypnoea of the newborn [1].

Both pre-gestational and gestational diabetes can lead to cardiovascular changes, but in the pre-gestational period, in which there is a possibility of altered glycemia during embryogenesis, there may be congenital heart disease such as transposition of the large arteries, right double ventricular entry pathway, truncus arteriosus, left ventricular hypoplasia syndrome and ventricular septal defect [2].

In gestational diabetes, the main structural alteration is myocardial hypertrophy, which can lead to transient subaortic stenosis and congestive heart failure [3], as happened in this report.

One of the main hypotheses of the reason for these alterations is related to fetal hyperinsulinemia, secondary to an increase in the synthesis of proteins and fats, independent of the amount of glycogen deposition [4], resulting from the increased presence of insulin receptors in the fetal heart [5].

Hyperglycemia, on temporary peaks, during the third trimester of pregnancy is essential for the development of myocardial hypertrophy and diastolic heart abnormality. These findings are found in both the babies of mothers with pre-gestational diabetes and those with gestational diabetes [3].

In addition, neonatal hypoglycaemia, which is more frequent in children of diabetic mothers, may be related to fetal hyperinsulinism, high C-peptide levels at birth, and $\beta$-cell function disturbance, leading to neonatal complications such as cardiomegaly and electrocardiographic abnormalities [6].

Changes in pulmonary vascular resistance and insulin hypersecretion may block the enzyme-inducing action of cortisol and the synthesis of lecithin, the main component of pulmonary surfactant, which contributes to respiratory distress $[3,7,8]$.

Multiple biochemical alterations occur in the presence of hyperglycemia, such as the cellular reduction of arachidonic acid and myo-inositol and the increase in the production of free oxygen radicals [9]. Those also are factors in the genesis of congestive heart failure [7].

A fetal echocardiogram with Doppler is suggested for tracing cardiovascular changes in these fetuses ${ }^{10}$. Every newborn diabetic mother should undergo, if possible, an echocardiogram within the first 12-48 hours of life to assess cardiac function or structural malformations. In cases where cardiac failure occurs, be careful with the administration of inotropes, as they are contraindicated, and newborns benefit from the use of beta-blockers (propranolol) [11].

Myocardial hypertrophy is probably transient and may disappear around six months to two years after birth [12], but in examinations of pathological anatomy of the heart of a diabetic mother's newborn, the same level of myofibrils disorganization was observed similar to found in adults with hypertrophic cardiomyopathy [13].

In an animal-induced diabetes study it was observed that the level of maternal hyperglycemia determines the type of cardiomyopathy and that the resolution of these would be associated with the activation of the signaling pathway of mitosis activating protein kinase and apoptosis pathways [14].

It has been reported that fetuses with macrossomia or restricted fetal growth, as occurs with the son of a diabetic mother, tend to be obese and diabetic in adulthood leading to an early cardiovascular event, such as acute myocardial infarction [15].

After reviewing the literature, we observed that it suggests the need for prenatal diabetes control and guidance to parents about the future risks these children may have in adult life

\section{Learning objectives / skills}

\section{- Importance of proper DMG management}

- Cardiovascular alterations of the newborn of diabetic mother

\section{Important points}

- Gestational diabetes is a disease present in $1.7 \%$ to $11.6 \%$ of pregnancies and has great relevance because it is a public health problem [16].

- The mother's son with gestational diabetes mellitus (GDM) is 20.6 times more likely to exhibit cardiovascular changes than a newborn from a non-diabetic mother [10].

- The main cardiac alteration present in the newborn is myocardial hypertrophy, which when severe may lead to transient subaortic stenosis and congestive heart failure [3].

- Inadequate management of gestational diabetes, especially untreated, may lead to cardiac change in the newborn.

- Differential diagnosis includes hypertrophic cardiomyopathy of genetic transmission or other secondary causes such as Friedreich's Ataxia, Pompe's Disease, Noonan's Syndrome, Congenital Hypothyroidism, Leopard's Syndrome and neurofibromatosis [17].

\section{References}

1. Binotto CN (2007) Análise comparativa da circulação fetal e transicional pelo Doppler ecocardiograma em feto e recém-nascido de gestantes diabéticas [Tese]. Curitiba. Universidade Federal do Paraná.

2. Corrigan N, Brazil DP, McAuliffe F (2009) Fetal cardiac effects of materna hyperglycemia during pregnancy. Birth Defects Res A Clin Mol Teratol 85: 523-530. [Crossref]

3. Kozak-Barany A, Jocinen E, Kero P, Tuominen J, Ronnemaa T, et al. (2004) Impaired left ventricular diastolic function in newborn infants of mothers with pregestational or gestational diabetes with good glycemic control. Early Hum Dev 77: 13-22. [Crossref]

4. Breitweser JA, Meyer RA, Sperling MA, Tsang RC, Kaplan S (1980) Cardiac septal hypertrophy in hyperinsulinemic infants. J Pediatr 96(3 Pt 2): 535-539. [Crossref] 
5. Rizzo G, Arduini D, Romanini C (1992) Accelerated cardiac growth and abnormal cardiac flow in fetuses of type I diabetic mothers. Obstet Gynecol 80(3 Pt 1): 369-376. [Crossref]

6. Freyschuss U, Gentz J, Noack G, Persson B (1982) Circulatory adaptation in newborn infants of strictly controlled diabetic mothers. Acta Paediatr Scand 71: 209-215. [Crossref]

7. Reller MD, Tsang RC, Meyer RA, Braun CP (1985) Relationship of prospective diabetes control in pregnancy to neonatal cardiorespiratory function. $J$ Pediatr 106 : 86-90. [Crossref]

8. Deorari AK, Paul VK, Singh M (1989) Echocardiographic assessment of infants born to diabetic mothers. Arch Dis Child 64: 21-24. [Crossref]

9. Gingel RL (1992) Developmental biology of mammalian myocardium. In: Freedom RM. Neonatal Heart Disease. Springler-Verlagp. 35-44.

10. Simões MA, Silva JC, Oliveira FM, Almeida LP, Binotto CN, et al. (2011) Análise Doppler Ecocardiográfica Fetal de Gestantes Portadoras de Diabete Melito Gestacional. Rev bras ecocardiogr imagem cardiovasc 24: 35-40.

11. Costa HDPF (2008) Recém-nascido de mãe diabética. In:Procianoy RS, Leone CR (Edtr). Prorn-Programa de atualização em neonatologia. Porto Alegre: p9-43.
12. Zielinsky P, da Costa MH, Oliveira LT, Bonow FP, da Silva N, et al. (1997) Natural history of myocardial hypertrophy and its association with hyperinsulinism in infants of diabetic mothers. Arq Bras Cardiol 69: 389-394. [Crossref]

13. Russel NE, Foley M, Kinsley BT, Firth RG, Coffey M, et al. (2008) Effect of pregestational diabetes mellitus on fetal cardiac function and structure. Am J Obstet Gynecol 199: 312-e1-7. [Crossref]

14. Reinking BE, Wedemeyer EW, Weiss RM, Segar JL, Scholz TD (2009) Cardiomyopathy in offspring of diabetic rats is associated with activation of the MAPK and apoptotic pathways. Cardiovasc Diabetol 8: 1-9. [Crossref]

15. Giuliano ICB, Carameli B, Pellanda L, Duncan B, Mattos S, et al. (2005) I diretriz de Prevenção da Aterosclerose na Infância e na Adolescência. Arq Bras Cardiol 6: 1-94. [Crossref]

16. Schneider S, Bock C, Wetzel M, Maul H, Loerbroks A (2012) The prevalence of gestational diabetes in advanced economies. J Perinat Med 40: 511-520. [Crossref]

17. Santana MVT. Cardiopatias Congênitas no Recém-Nascido: Diagnóstico e Tratamento. São Paulo: Atheneu; 2000

Copyright: (C2019 Pabis JSThis is an open-access article distributed under the terms of the Creative Commons Attribution License, which permits unrestricted use, distribution, and reproduction in any medium, provided the original author and source are credited. 